Прегледни чланак

343.712:343.14(497.11)

doi:10.5937/zrpfns54-24792

Saša N. Dmitrašinović, Ph.D. Student

University of Novi Sad

Faculty of Law Novi Sad

sadmiso65@gmail.com

\title{
POLICE OPERATING AND EVIDENCE PROCEDURES IN RESOLVING THE CRIMINAL ACT OF ROBBERY IN THE REPUBLIC OF SERBIA
}

\begin{abstract}
The criminal act of robbery is a complex criminal act in the field of property crime with the elements of violence, as stated in the Criminal Law of the Republic Of Serbia by the Provision 206 of the Criminal Law. The dynamics and the frequency of the manifestations of such criminal acts in everyday life, along with the scope and the intensity of the consequences, all contribute to the continual interest in the research and in the need to provide a deeper insight into this phenomenon. The focus of this research, therefore, is on recognizing the state and tendencies, and on taking specific measures in the field of confronting the acts of robbery. More specifically, the paper mainly examines the police operating procedures in implementing operating and evidence procedures and in criminal processing and resolving the criminal act. The paper is particularly focused on the comparative analysis of operating and evidence procedures, and their interdependency in efficient resolving of criminal acts and in raising evidence.
\end{abstract}

Keywords: robbery, police operating procedures, evidence procedures, criminal processing.

\section{INTRODUCTION}

The criminal act of robbery is prescribed in the Criminal Law of the Republic of Serbia ${ }^{1}$ by the Provision 206, chapter XXI in the field of criminal acts against property.

${ }^{1}$ Criminal Law ("Official Gazzette of the Republic of Serbia", no. 85/2005, 88/2005 corrected, 107/2005 - corrected, 72/2009, 111/2009, 121/2012, 104/2013, 108/2014, 94/2016 and $35 / 2019)$ 
Property offences can be classified into typical offences; offences with the elements of physical violence; adultery offences and offences without mercenary motives. ${ }^{2}$

The act of robbery is a complex criminal act, the characterized by the criminal act of coercion, and consisting of deprivation of other person's assets with the goal of attaining material benefit towards oneself or others, using force against the other person or using threats to directly assault life or body.

The law defines the criminal act of robbery to be a two-sided criminal act which requires two cumulative actions to be taken: both the force or threat and seizing other person's assets. The first action taken is the act of coercion, i.e. the act of force or threat to assault life or body, followed by the act of seizure, or coercion as a means of seizing the assets. ${ }^{3}$

The Criminal Law prescribes the basic form of robbery, two qualified and one minor form of committing the criminal act. There are other forms of criminal act in case the basic form of a criminal act has been done by a group, ${ }^{4}$ in case the offender has intentionally committed an infliction of serious bodily harm during the act of robbery, or in case the value of the seized assets exceeds the amount stated by the Criminal law (one million and five hundred thousand dinars). The act is qualified as a major criminal act of robbery in case the basic form of the act has been done by an organized criminal group. ${ }^{5}$ The act is qualified as a minor, or privileged form of the act, in case the value of the seized assets when committing the basic form does not exceed fifteen thousand dinars, with the obligatory condition of having the intention of acquiring minor material benefit on the part of the person committing the act.

The phenomenon of robbery is heterogeneous, particularly in terms of its manifestations. In criminal practice, it is expressed in the forms of bullying, robbery in smaller grocery shops, but also in the form of criminal acts committed by organized criminal groups by ways of armed robberies in money transport, in banks and other financial institutions.

The way in which a criminal act is committed, especially as a way of an organized criminal action is, by the rule, the use of force and threats of using cold

\footnotetext{
${ }^{2}$ Milo Bošković, Miloš Marković, Kriminologija sa elementima viktimologije, Novi Sad 2015, 201.

${ }^{3}$ More in: Zoran Stojanović, Komentar Krivičnog zakonika, četvrto izmenjeno i dopunjeno izdanje, Edicija Komentari zakona, SLužbeni glasnik, Beograd 2012, 616.

${ }^{4}$ Provision 112, paragraph 2 to the Criminal Law, defines a group as consisting of at least three persons related with the goal of committing permanent or temporary criminal actions, which does not need to be defined in terms of its members' roles, the continuity of their membership or the structural development.

${ }^{5}$ Provision 112, paragraph 35 to the Criminal law defines an organized criminal group as a group of three or more persons, which has been existing for a certain period and has been taking actions with the goal of committing a single or multiple criminal acts that may be sanctioned by the prison sentence of four years or more, in order to directly or indirectly gain financial or other benefit.
} 
or fire weapons. The most frequent means in committing such a criminal act is physical force, fire weapons or a copy of a fire weapon resembling the original. The following fire weapons are usually used: a pistol, a gun, an automatic pistol or an automatic rifle. Other means of execution are also used, such as cold weapons, various types of blades (a knife, a dagger, an axe), mines or explosives and various other disabling sprays. ${ }^{6}$

Criminal offenders are organized in such a way that they enter into committing a crime in a planned and organized way and leave the crime scene quickly. When committing a crime, depending on the object of the assault, it is possible to employ various modes, but they all have one characteristic in common: a sudden break-in into the object of the assault, the surprise factor, supressing security and preventing potential resistance, taking money or obtaining other benefit, and a fast runaway from the crime scene. A sudden break-in is characteristic for all the robberies, whereas organized robberies bear this characteristic as the prominent one. The surprise factor, without any doubt, represents the crucial factor to a successful robbery, which is something the offenders are aware of. The more surprise there is, or, the higher the effect is, the higher the efficacy of the criminal activity is. ${ }^{7}$

Offenders of the criminal acts of robbery are by rule repeated offenders in committing violent acts, without empathy for the victims of criminal acts, especially when the committers are groups with smaller or higher degree of organization.

There is a concerning tendency in the rise of the acts of felony and in the victim's physical state. Researches show that the repercussions of a trauma to the victim can be significant and long-lasting. ${ }^{8}$

Regarding the complex definitions of this criminal act from the aspect of phenomenology of the act of robbery and the use of force and threat in committing a criminal act, the criminal police that has the jurisdiction over suppression of crime, uses a wide range of operating and evidence procedures in detecting and pleading a criminal act of robbery.

The general legal framework in employing operating and evidence procedures of the police has been enacted by the Law on Criminal Procedure ${ }^{9}$, and by the Law on Police. ${ }^{10}$

Operating and tactical actions are taken by the police in case there is a reasonable doubt that a criminal act has been committed, and the offenders are prosecuted

${ }^{6}$ More in: Warren J. Sonne, Criminal Investigation fro the Professional Investigator, Boca Raton 2006, 73-84.

${ }^{7}$ Cf. Bernasco Wim, Block Richard, „When Offenders Choose to Attack: A Discrete Choice Model of Robberies in Chicago" Criminology, 47/2009, 93-130.

${ }^{8}$ Willan Matthews, Armed Robbery, Devon: Willan Publishing 2002, 78.

${ }^{9}$ The Law on Criminal Procecudre ("Official Gazzette of the Republic of Serbia", no. 72/2011, 101/2011, 121/2012, 32/2013, 45/2013 and 55/2014).

${ }^{10}$ The Law on Police ("Official Gazette of the Republic of Serbia", no. 6/2016, 24/2018 and 87/2018) 
by the law (Law on Criminal Procedures, Provision 286); in other words, when the police is performing its primary duty of resisting the crime, aforementioned actions are not used as evidence, but are of operating significance in resolving the circumstances of the committed criminal acts and in channeling the course of the criminal investigation.

Evidence procedures are the procedures implemented by police officers as required by the law, in the prescribed cases when there is a possibility of the adjournment, and these are used as evidence. Evidence obtained in such a way, by implementing evidence procedures in the prescribed form of the law, can be used as evidence in criminal procedure.

Having in mind the significance of protecting basic property and assets, the scope and intensity of the committed robbery, the paper comparatively analyzes police operating and evidence procedures by postulating the essential question of whether their mutual and complementary implementation is necessary in resolving all the circumstances regarding criminal acts, and in adducing valid evidence.

\section{OPERATING ACTIONS TAKEN BY THE POLICE IN PROCESSING A CRIMINAL ACT OF ROBBERY}

Operating-tactical actions taken by the police in suspending crime are employed without a strictly stated process form, while the information obtained in such a way cannot be used as evidence in the criminal proceedings. Still, such activities have a specific significance in resolving the circumstances of the committed criminal acts, and in channeling the criminal investigation.

Specific provisions of the Law on Criminal Procedure and the Law on Police provide a legal basis for the police operating activities.

The authority of the criminal police is primarily in charge of uncovering and resolving criminal acts, as stated by the Law on Criminal Procedure, Provision 286. The work on uncovering criminal acts and their offenders represents the main duty of the criminal police. ${ }^{11}$

In case there is a reasonable doubt that the committed criminal act is prosecuted ex officio, the police directly implements the measures and the actions with the goal of finding the offender and the partners in the crime, preventing their escape, uncovering and of securing the criminal act clues and objects that may serve as evidence, and of obtaining all the information that may be used in successful implementation of the criminal procedure (Provision 286, paragraph 1, Law on Criminal Procedure).

${ }^{11}$ Goran P.Ilić, Miodrag Majić, Slobodan Beljanski, Aleksandar Trešnjev, Komentar Zakonika o kriviičnom postupku, deseto izmenjeno i dopunjeno izdanje, Edicija komentari, Službeni glasnik, Beograd 2018, 753. 
When implementing these law stated actions, the police employs a number of the prescribed measures and actions ${ }^{12}$ and other measures and actions specially prescribed by the law. By the order of the court in previous procedures, and by the public attorney's motion, the police may obtain evidence of the phone communication, the use of cell towers, or may locate the place at which the communication is taking place (Provision 286, paragraph 3, Law on Criminal Procedure).

The Law on Police is the legal act, organizational and functional in its character. This Law enacts organizations and jurisdictions of the Ministry of Internal Affairs and the Police Directorate, while specific prescriptions foresee the measures taken by police officers in performing police duty. Such measures are uncovering and resolving criminal acts, providing evidence, analyzing the evidence, using criminal-forensic expertise by modern forensic methods and evidencing and finding the assets taken in the criminal act itself, all prescribed as a specific type of the police job (Provision 30, paragraph 3, item 2, Law on Police). The Law specifically prescribes the police measures and actions regarding the police tasks (Provision 47, Law on Police).

The following police measures and observations are of particular significance: polygraph examination; searching for people and objects as a criminal forensic registration, taking other samples and performing criminal forensic expertise and analyses (Provision 47, paragraph 3, items 3,7,9 and 12 of the Law on police).

The tactics and the methodology of the police procedures in criminal processing, open and enforced, related to the committed criminal act of robbery, are defined by criminalistics as a science, the experience of good criminalistic practice and by the specific circumstances of the committed criminal act.

In order for the criminal processing to provide results, the practice procedure needs to provide a link between the theoretical conception and practice, while theoretical knowledge should be verified through direct operative proceedings. ${ }^{13}$

With the goal of efficiently resolving and evidencing the criminal act of robbery, police officers need to employ a number of operating (and evidence) measures and acts. A specific number of measures and acts, prioritizing the principle of urgency, are employed directly upon the first notice on the committed criminal act, some of them being employed continually during the criminal processing.

12 Provision 286, paragraph 2, of The Law on Criminal Procedure states that the police is allowed to do the following: to ask for the necessary information from the citizens; to inspect and check vehicles, passengers and luggage; to restrict a person from the right of movement in a specific territory for a required time, not longer than 8 hours; to take the necessary actions in order to claim the authenticity of persons and objects; to issue a wanted circular for persons and objects; to inspect, in the attendance of a person in charge, certain objects and premises in state organs, companies, shops and other legal parties; to gain insight into their documents and to seize them if necessary; to take other necessary measures and actions.

${ }^{13}$ Vladimir Krivokapić, Uvod u kriminalistiku, Beograd 2008, 130. 
Criminal processing is an organized activity of internal affairs authorities with the specially emphasized criminal repressive character, where operating-tactical actions and measures are taken in order for the initial information (particulars of doubt) on the existence of the specific criminal act or on the offender, to be eventually confirmed. This should raise the probability level of uncovering the fact that a specific person has committed a specific criminal act for which the person is prosecuted ex officio; in that way the conditions for lawfully brining the offenders to criminal prosecution should be provided. ${ }^{14}$

The measures and actions carried out by the principle of urgency upon committing and reporting the criminal action of robbery, may be viewed through the three separate segments of the operation work.

One way of the criminalistic operating actions is directly related to the evidence action the crime scene examination. These are primarily the general activities of the police and are related to securing the crime scene, with the special focus on securing the unchangebleness of the crime scene until the crime scene investigation team (the organs) arrives.

Of particular importance are the operating actions of the police officers crime technicians in finding clues, in photographing and scanning the crime scene. It is of particular importance to bear in mind that specific clues, found or taken at the crime scene, such as traces of papillary lines, may be the subject of expertise evidence procedure during the course of criminal procedure.

The other segment consists of the measures of urgent observations, examination of the persons, vehicles and objects, and search for persons or objects. These measures are taken through the so-called police blockade, by ways of controlling the persons and the objects in the wider area of the crime scene. The main goal of this segment of operative work is to catch the offenders on the spot or immediately upon committing the crime, and to find the objects and the instruments used in the crime. In case objects or instruments used in the crime have been found, these operating actions taken by the police will be used as a reason for taking evidence procedures in temporary seizure of the objects and in (or) search of the premises. In case the offender is found, the specific measure of police arrest will be taken, followed by the measure of escorting the offender to the public attorney in charge (Provision 291, Law on Criminal Procedure).

Obtaining information from the citizens at the crime scene is the third segment of urgent actions taken by the police. Of particular importance is the first operating information about the criminal action and the offender, which is gathered without any time distance, within a short interval of the crime committed. The necessary information is obtained from the parties injured in the criminal act,

\section{2,118}

${ }^{14}$ Branislav Simonović, Kriminalistika, Treće izmenjeno i dopunjeno izdanje, Kragujevac 
from witnesses or other parties that have direct information of the committed crime (offenders entering or leaving the crime scene, the vehicles used etc.).

In case the urgent operating activities by the police do not result in resolving the criminal act, the continuation of operating procedures employs some of the urgently taken measures and actions, but also other operating-tactical measures and actions with the goal of efficiently resolving and clarifying criminal acts.

The internal affairs authorities are required to build up the methods and the means by which those who are most efficient in unclosing criminal acts and offenders will be engaged. The essence of this operating action consists of taking measures and actions to unclose criminal acts and to secure the clues and objects in order for them to be used as evidence in the criminal proceeding. ${ }^{15}$

In this way, the operating action of obtaining information from the citizens is continually done during the criminal procession. The Law particularly prescribes the police to be allowed to summon citizens and to convey the person not acting by the summons only if the person has been warned prior to conveying (Provision 288, paragraph 1, Law on Criminal Procedure). The means and the conditions of employing this measure, its restrictions, the procedure and preconditions for gathering information from specific categories of citizens, like detainees, have also been prescribed by the law (Provision 288, paragraphs 3-7, Law on Criminal Procedure).

The sources of information can be various categories of citizens who have some information about the criminal act committed and the offender, therefore the persons from criminal environment have specific contacts and relations with police officers in the criminal police. Most often, these persons are so called informants with whom police officers keep professional contacts in order to gather direct insight into the criminal environment, or keep contacts with other persons who willingly provide police officers with the specific information. ${ }^{16}$

The tactics and the methods of gathering information must be adapted to the general and specific characteristics of the persons gathering the information.

The information interview should be done by an experienced officer with a vast knowledge in criminal tactics and in the methodology of the specific types of criminal acts. The officer is expected to have a thorough knowledge in psychology of various categories of people, to have social intelligence (which means to be patient in treating the person being interviewed, to be adaptable to the person being interviewed, to be communicative, to think and react quickly during the interview, to have the ability to carefully listen, to think and to study the person's reactions at the same time). ${ }^{17}$

${ }^{15}$ V. Krivokapić, ibid 133.

${ }^{16}$ More in: Tatjana Lukić, Posebnosti krivičnog postupka za organizovani kriminal, terorizam i korupciju, Novi Sad 2008, 174-198.

${ }^{17}$ B. Simonović, ibid 123. 
While gathering information from the citizens, the police can not conduct the hearing of the citizens ad being suspects or experts, unless special conditions for Hearing the suspect are fulfilled, in which case the police is allowed to conduct the hearing of the suspect by the provisions of the Law on hearing the suspect (Provision 289, Law on Criminal Procedure).

In uncovering criminal acts, many other non-evidence criminal-tactical measures and actions are also taken. These comprise using various records, video surveillance records, or measures like inspection of the premises and the persons, so called riots, but also the measures of criminal techniques like taking traces of papillary lines or DNA samples. Polygraph examination is also carried out in police investigations concerning the circumstances of the criminal act of robbery and its resolving. This operative activity performed by police officers is prescribed as a specific type of police measures and actions (Provision 57, Law on police). The required precondition of the polygraph examination is the willful acceptance of the examination on the part of the person being examined; the person examined is asked to submit their free will consent in written form. Polygraph examination can not be undertaken on persons who are under the influence of alcohol, drugs or other psychoactive substances, on persons with severe heart diseases or respiratory distress, on persons who are under stress; on persons who are sedated; on persons exhibiting visible signs of mental illness, temporary psychic alienation or on persons exhibiting other forms of illnesses that prevent interrogation; on persons experiencing intensive physical pain; on pregnant or nursing women; on persons under the age of 14 (Provision 57, paragraph 4, items 1-8 Law on Criminal Procedure). Minors can be tested on the polygraph only with their personal consent and under the presence of their parent, guardian or an adult person of discretion. The person of discretion may be the person who is close to the minor in various terms, mainly persons taking part in the process of education or socialization of minors (teachers, employees of the Social welfare center, educators in the field of sport etc.).

In criminal procession, polygraph may be used as a technical aid in order to quickly and a relatively reliable way eliminate innocent persons from the range of suspects. In this way, the operative activity is focused on the probable offender, on obtaining information from him/her and on finding material carriers of evidence information. ${ }^{18}$

The significance of polygraph testing is in gathering information about the possible offender of the criminal act, about unclosing specific important circumstances in performing or directing the course of the criminal procession. Moreover, it can help in possible exclusion (elimination) of a specific person from the range of suspects, especially in cases when polygraph testing results are in accordance with other gathered information in the criminal investigation.

${ }^{18}$ Ibid, 126. 
When taking operative, informal measures and actions in preliminary procedure, the police needs to bear in mind the law stated role of public attorney. Apart from the significantly important duties of prosecuting the criminal offender in the criminal proceedings, public attorney is also in charge of the preliminary procedure (Provision 43, paragraph 2, item 1 of Law on Criminal Procedure). In this way, public attorney may allow the police to take specific measures or actions or may take these by himself/herself, although the criminal practice normally exhibits a consensus between public attorney and the police in terms of taking operating actions.

\section{EVIDENCE PROCEDURES BY THE POLICE}

The police employs evidence facts in criminal procedures when unclosing criminal acts and finding offenders. There are evidence procedures which, by the principle of urgency in acting, the police may independently take as being given the approval or as being permitted by the other authority in the procedure. ${ }^{19}$ The police may entrust the evidence facts to the public attorney (Provision 299, paragraph 4, Law on Criminal Procedure) even after the investigation has begun, as stated by the Law.

The crime scene investigation, by rule, represents the first evidence procedure done by the police or by another proceeding authority, which is done on the crime scene in case of the criminal act of robbery, with the goal of identifying and clarifying the relevant facts (Provisions 133-136 Law on Criminal Procedure).

While taking the crime scene investigation, it is usually various professionals that are engaged there, with the aim of finding, securing or describing the criminal act clues (Provision 133, paragraph 3 of the Law on Criminal Procedure). Of special significance are the activities done by the police officers - crime technicians who are employed in finding and fixing the clues of the criminal act. The crime scene may, therefore, provide various clues coming from the offender (biological traces, papillary lines) or from the instruments used in the robbery, such as mechanical traces of the instruments or fire arms traces. The information gathered and the clues obtained are written down in the record made according to the investigation, which is a necessary precondition in taking other evidence procedures in the criminal proceedings, like expertise of the found and the sampled criminal act clues (Provisions 113-132 of the Law on Criminal Procedure).

Material clues found at the crime scene are subject to particular expertise and may therefore be used as material evidence, as well as the objects that have

\footnotetext{
${ }^{19}$ More in: G.P. Ilić, et al. ibid 759-760.
} 
been robbed, but found and taken from the offender during the investigation process of searching the premises. ${ }^{20}$

Police officers - crime technicians employ the specific crime-technical procedure in identifying the persons (offenders) on the basis of the detected and lifted papillary line traces, which is specifically discussed and given opinion of, and which may be used in the criminal proceeding as a separate evidence. The rule is that such a technique of expertise is done by the persons with the proper knowledge in crime technique; their findings and their opinion (expertise) may be used as material evidence in the criminal procedure.

Taking the first evidence action in criminal investigations is particularly important in the criminal proceedings, as from the day of taking the first evidence action by the police or by the public attorney there is a 30 day period within which the attorney needs to decide on launching (or not launching) the investigation, or the criminal proceeding (Provision 296, paragraph 2 of the Law on Criminal Procedure).

Criminal police, when processing a crime, particularly felonies such as robbery, traditionally takes evidence actions regarding Temporary seizure of objects acquired by the felony or of objects used in the criminal act (Provisions 147-151 of the Law on Criminal Procedure). In order to find the suspect, the clues or the objects related to the criminal act, police officers may conduct Search as the evidence action (Provisions 152-160 of the Law on Criminal Procedure).

The Search procedure may be done on the basis of the court order, and on the well grounded opinion of the public attorney (Provision 155 of the Law on Criminal Procedure) or without the order (Provision 158 of the Law on Criminal Procedure) in case there are urgent conditions as stated by the law (agreement of the tenant to search the flat and other premises, in case there are calls for help, in case of the direct arrest of the offender, in case of enforcing the court order on confinement or bringing the suspect and in case of removing the direct and serious threat to the people or the assets).

Criminal procession of the committed criminal act of robbery and the aforementioned evidence acts may be preceded by operating-tactical measures of inspecting persons or objects, applied directly upon the committed criminal act with the goal of tracking down the offenders and finding the objects and means of the criminal act. In cases when the inspection of persons or premises results in finding the objects or means of the criminal act, evidence action of temporary seizure of objects and (or) the evidence action of searching will be taken.

When the police is in charge of obtaining and securing the evidence, the prescribed authority of examination of the suspect is of particular significance (Provision 289 of the Law on Criminal Procedure). When gathering the information from the persons which are under reasonable doubts of being the offenders (in the

${ }^{20}$ Mićo Bošković, Kriminalistička metodika, Beograd 2005, 149. 
criminal act of robbery) or from the citizen who, during the process of gathering information, is found to be the suspect, the police officers may conduct the examination of such suspects as stated by the provisions of the Law on Criminal Procedure and the Examination of the Suspect. ${ }^{21}$

In case the suspect expresses willingness to give evidence in the attendance of the defender, the record on examination has the power of evidence and may be used as evidence in the criminal proceeding.

The efficacy of implementing this action depends on the quality of the preliminary operating findings and on the degree of resolving the state of facts regarding criminal aspects.

In case the required necessary information about the criminal act and the offender has been gathered, and other operating-tactical (and evidence) measures and actions have been taken, all providing a grounded version of the committed criminal act and the offender, the examination of the suspect will provide the main goal of this action in obtaining evidence.

When gathering evidence for qualified forms of robbery as stated in Provision 206, paragraph 2 (in case the act of the first paragraph has been committed by a group, or a grievous bodily harm with intent has been done to a person or in case the value of the robbed assets exceeds one million and five hundred thousand dinars) and in paragraph 3 (in case the criminal act has been done by an organized criminal group) of the Criminal Law, police officers, acting upon the court order brought on the basis of the public attorney's detailed motion, may employ Specific evidence actions (Provisions 161-180 of the Law on Criminal Procedure). The conditions and restrictions of employing specific evidence actions, and the manner of employing them, are stated by the law. It concerns specific measures that impend to some extent the rights of privacy guaranteed by the Constitution; they are therefore restrictively employed only when the acts of felony have been committed and when other methods can not achieve the results of the criminal procedure. ${ }^{22}$

\section{CONCLUSION}

The criminal act of robbery is a felony in the filed of property crime, with elements of physical violence, both in the method of committing the crime using force and threat and in the consequences to the property and other rights on the part of the victim of the criminal act.

${ }^{21}$ The authority in charge needs to introduce the specific rights of the defendant to the defendant prior to the first hearing at the court; the rights are prescribed by Provision 68, paragraph 1, items 2-4 and item 6, while the regulations for hearing the defendant are prescribed by Provisions 85-90 of the Law on Criminal Procedure.

${ }^{22}$ More in: Tanja Bugarski, Posebne dokazne radnje, Novi Sad 204, 23-31 
While searching and investigating felonies like robbery, while searching for the offender, gathering and securing the evidence, criminal police in charge of suppression of crime employs a wide range of operative-tactical and evidence measures and actions.

The general legal framework regarding police activities in suppression of crime is defined by the Law on Criminal Procedure and by the Law on Police. There are also prescribed operative, informal measures and actions that do not result in directly obtaining evidence; still, there are evidence actions that police officers take when it is necessary to act urgently in obtaining evidence. In case the evidence actions are taken in the prescribed processing form and by the law, the evidence obtained may be used in the criminal proceedings.

The tactics and the methodology of criminal actions is conditioned by the methods of criminalistics as a science, of the experiences in good criminalistic practice and of the conditions and the weight of the committed criminal act.

With the aim of efficiently resolving felonies, criminal acts such as robbery, it is necessary to simultaneously implement a wide specter not only of operating but also of evidence measures and actions.

Operating and evidence actions taken by the police represent a unique whole, both in the field of the goals set in resolving the circumstances of committed crimes, and through criminalistic practice in searching for the offenders, objects, clues and evidence that may be of use in the criminal procedure.

When taking operating and evidence measures, criminal procession may define the logical relation between these two types of police procedure, as the efficient implementation of one type of actions depends on taking the other type of measures and actions, and in some cases evidence actions follow directly from operating measures and actions.

The goal of taking examination measures towards the suspect may be obtained only if other operative measures and actions have been taken before, regarding all the conditions of the committed criminal act, while operating actions, such as inspection of persons or premises, taken immediately upon committing the crime and on the principle of urgency, directly implement evidence procedures of temporary seizure of objects and search of premises.

Operating and evidence actions taken by the police during preliminary investigation, regardless of their different legal nature, or due to their different legal nature, represent a compatible whole in achieving the main goals of both the preliminary and the criminal procedure in obtaining evidence and bringing the offenders to justice. 


\section{REFERENCES}

Bernasco Wim, Block Richard, „When Offenders Choose to Attack: A Discrete Choice Model of Robberies in Chicago "Criminology, 47/2009.

Bošković, Mićo, Kriminalistička metodika, Beograd 2005.

Bošković, Milo; Marković, Miloš, Kriminologija sa elementima viktimologije, Novi Sad 2015.

Bugarski, Tanja, Posebne dokazne radnje, Novi Sad 2014.

Goran P. Ilić; Majić, Miodrag, Beljanski, Slobodan, Aleksandar Trešnjev, Komentar Zakonika o krivičnom postupku, deseto izmenjeno i dopunjeno izdanje, Edicija komentari, Službeni glasnik, Beograd 2018.

Zakonik o krivičnom postupku (,Sl. Glasnik RS“, br. 72/2011, 101/2011, 121/2012, 32/2013, 45/2013 i 55/2014).

Zakon o policiji (,,Sl. Glasnik RS“, br. 6/2016, 24/2018 i 87/2018).

Krivični zakonik (,Sl. Glasnik RS“, br. 85/2005, 88/2005 - ispr., 107/2005 - ispr., 72/2009, 111/2009, 121/2012, 104/2013, 108/2014, 94/2016 u 35/2019).

Krivokapić, Vladimir, Uvod u kriminalistiku, Beograd 2008.

Lukić, Tatjana, Posebnosti krivičnog postupka za organizovani kriminal, terorizam i korupciju, Novi Sad 2008.

Simonović, Branislav, Kriminalistika, treće dopunjeno i izmenjeno izdanje, Kragujevac 2004.

Stojanović, Zoran, Komentar Krivičnog zakonika, četvrto izmenjeno i dopunjeno izdanje, Beograd 2012.

Warren J. Sonne, Criminal Investigation for the Professional Investigator, Boca Raton 2006.

Willan Matthews, Armed Robbery, Devon: Willan Publishing 2002. 


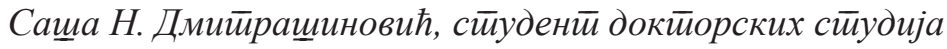
Универзииетеи у Новом Саду

Правни факулиетеи у Новом Саду

sadmiso65@gmail.com

\section{Оперативне и доказне радње полиције у расветљавању кривичног дела разбојништва у Републици Србији}

Сажейак: Кривично дело разбојнищӣва сложено је кривично дело из областии имовинског криминалийейа са елементимма насиља, йройисано у Рейублици Србији чланом 206. Кривичног̄ законика. Динамика и фреквенција

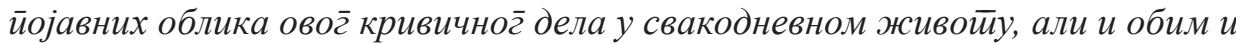

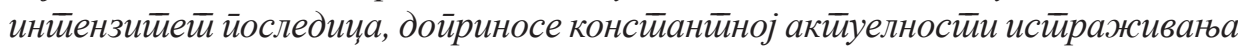
и йотиреби исирйније сйознаје овог̄ феномена. Сйог̃ фокос нашег̃ истираживања усмерен је на ког̄начију стйьь и ииенденција, као и конкрейних мера у областии суйройстивљљања кривичном делу разбојнищитва. Конкрейно у раду се доминаниино размайра оиеерайивни рад йолииије, у иримени оиеерайивних

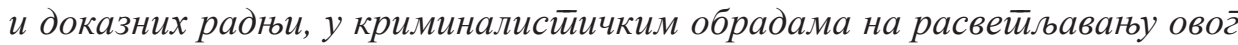
кривичног дела. Посебан фокус усмерен је на комйарайивну анализиу ойератиивних и доказних радюи, йе њихову међузависности у ефикасном расвейљавању кривичних дела и ирикуйьању доказа.

Кључне речи: разбојнищйво, ойерайивне радње йолищије, доказне радње, криминалистиичка обрада.

Датум пријема рада: 14.01.2020. 